\title{
ANALISIS PREDIKSI KEBANGKRUTAN PADA PT BENTOEL INTERNATIONAL INVESTAMA Tbk
}

\section{ANALYSIS OF BANKRUPTCY PREDICTION IN BENTOEL INTERNATIONAL INVESTAMA Tbk}

\author{
Irmah Halimah Bachtiar ${ }^{1,}$ Jumriah Basri ${ }^{2}$ \\ ${ }^{1}$ Akuntansi, Universitas Indonesia Timur \\ (irmahalimah@gmail.com) \\ ${ }^{2}$ Manajemen Keuangan, Sekolah Tinggi Ilmu Manajemen Nitro \\ (jumriahbasri1@gmail.com)
}

\begin{abstract}
ABSTRAK
Adanya kondisi keuangan perusahaan PT Bentoel International Investama Tbk. menggambarkan ketidakstabilan, maka penting sekali untuk menganalisis kondisi perusahaan ke depannya, serta perkembangan dan peningkatan kinerja keuangan pada perusahaan tersebut. Penelitian ini bertujuan untuk menganalisis prediksi kebangkrutan pada PT Bentoel International Investama Tbk. Metode analisis yang digunakan dalam penelitian ini adalah metode Altman Z-Score, dengan menggunakan tiga kreteria yaitu zona aman, grey area dan zona berbahaya. Hasil penelitian menunjukkan bahwa PT Bentoel International Investama Tbk. berpotensi mengalami kebangkrutan.

Kata Kunci : Prediksi kebangkrutan, laporan keuangan, model analisis altman z-score

ABSTRACT

The financial condition of the company PT Bentoel International Investama Tbk. describing instability, it is very important to analyze the condition of the company going forward, as well as the development and improvement of financial performance of the company. This study aims to analyze the predictions of bankruptcy at PT Bentoel International Investama Tbk. The analytical method used in this study is the Altman Z-Score method, using three criteria, namely safe zone, gray area and dangerous zone. The results of the study indicate that PT Bentoel International Investama Tbk. potentially bankrupt.
\end{abstract}

Keywords: Bankruptcy predictions, financial reports, altman z-score analysis models

\section{PENDAHULUAN}

Indonesia adalah salah satu negara yang masih pro-kontra terhadap regulasi rokok. Pemerintah Indonesia ingin mengurangi konsumsi rokok yang sangat berbahaya bagi kesehatan. Namun di sisi lain, industri rokok sendiri termasuk industri yang menyerap tenaga kerja terbesar di Indonesia, serta memberikan pendapatan pajak terbesar bagi pemerintah.

Rokok sudah seperti menjadi kebutuhan primer di Indonesia. Banyaknya masyarakat yang ikut mngkonsumsi rokok, baik orang dewasa bahkan remaja dan anak kecil, membuat rokok sudah merupakan bagian dari kebutuhan seharihari. Besarnya jumlah perokok serta pendapatan yang disumbangkan ke negara, membuat industri rokok memiliki peranan yang cukup penting terhadap pertumbuhan NKRI.

Industri rokok merupakan penyumbang pendapatan Negara yang cukup besar, baik di Negara berkembang maupun maju. Pada tahun 2004 rokok mampu menyumbang devisa Indonesia sebesar 16,5 Triliun sedangkan pada tahun 2011 sumbangan dari cukai rokok mencapai 62,759 Triliun. Dari data tersebut terlihat tren kecenderungan meningkatnya pendapatan yang diperoleh dari industri rokok. Hal tersebut dapat dipengaruhi oleh Pengelolaan keuangan yang merupakan hal penting untuk kemajuan dan 
perkembangan perusahaan rokok. Oleh karena itu setiap perusahaan memerlukan perencanaan strategi dan perencanaan yang baik dalam menjalankan usahanya agar dapat tetap bertahan dan berkembang. Rokok merupakan salah satu produk yang boleh dikatakan hampir tidak memiliki manfaat bagi yang mengkomsumsinya, namun realita kehidupan yang ada tak bisa dinafikkan bahwa produk rokok justru seperti menjelma dari produk yang dikonsumsi atas dasar "Kesenangan" menjadi sebuah "Kebutuhan". Hal seperti itu dapat kita jumpai dari banyaknya perilaku masyarakat yang slalu ingin menikmati atau mengkonsumsi produkproduk yang sudah sangat jelas dikategorikan mengandung zat berbahaya bagi kesehatan. Mengingat akan betapa pentingnya kesehatan bagi masyarakat serta besarnya bahaya yang timbul dari pada merokok maka pemerintah dan beberapa lembaga swadaya masyarakat lainnya melakukan sebuah peran yang sangat penting guna mencegah dampak dari pada bahaya merokok. Dimana pemerintah telah mengeluarkan UU No. 36 Tahun 2009 dan Peraturan Pemerintah (PP) 109/2012 ini di berlakukan akhir 2012.

Banyak regulasi yang telah dibuat oleh pemerintah dalam rangka melakukan pengamanan terhadap produk yang mengandung zat adaktif ini, mulai dari menaikan tarif cukai rokok, sampai pembatasan produksi, pembatasan luas areal perkebunan tembakau sebagai bahan baku, pembatasan promosi produk, pembatasan kawasan bebas merokok, serta ditambah pula lagi dengan kebijakan lembaga agama yang terdapat di Indonesia yaitu Majelis Ulama Indonesia (MUI) dan Muhammadiyah yang menfatwakan bahwa merokok haram bagi anak-anak, wanita hamil, dan di tempat umum. Semua itu dilakukan dengan dalih bahwa merokok hanya akan menimbulkan beban bagi kesehatan, sosial, ekonomi dan lingkungan tidak saja bagi perokok namun juga bagi orang orang lain.
Kebangkrutan diartikan sebagai kegagalan perusahaan dalam menjalankan operasi untuk mencapai tujuannya. Kegagalan ekonomis berarti bahwa pendapatan perusahaan tidak mampu menutupi biayanya sendiri. Sedangkan kegagalan keuangan berarti perusahaan tidak dapat memenuhi kewajibannya yang harus dipenuhi, walaupun total nilai asset melebihi kewajiban totalnya. Salah satu perusahaan rokok yang mengalami dampak dari kebijakan pemerintah adalah PT Bentoel International Investama Tbk. Perusahan terbesar yang ada di Indonesia ini dalam beberapa tahun terakhir mengalami masalah serius dalam menghasilkan laba perusahaan.

Data awal yang diperoleh mengenai kondisi keuangan PT Bentoel Internasional Investama Tbk. dari tahun ke tahun mengalami penurunan laba mulai dari tahun 2012 - 2014 sejak di berlakukannya UU No. 36 Tahun 2009 mengenai kesehatan, pada bagian aset lancar, 2011 ke tahun 2012 mengalami kenaikan sebanyak 4\%, 2012 ke 2013 naik sebanyak 24\%, 2013 ke 2014 naik sebanyak 9\%. Pada bagian asset tidak lancar, $2011 \mathrm{ke}$ 2012 naik sebanyak 20\%, tahun 2012 ke 2013 naik sebanyak 50\%, 2013 ke 2014 naik sebanyak $14 \%$. Dari sisi liabilitas lancar, 2011 ke tahun 2012 mengalami penurunan sebanyak 29\%, 2012 ke 2013 mengalami kenaikan kembali sebanyak 72\%, 2013 ke 2014 mengalami kenaikan sebanyak 28\%. Dari sisi total liabilitas, tahun 2011 ke tahun 2012 naik 23\%, tahun 2012 ke 2013 naik lagi sebesar 67\%, tahun 2013 ke 2014 naik lagi sebesar 35\%. Dari sisi laba bersih, dari tahun 2011 ke tahun 2012 megalami penurunan laba yg cukup drastis hingga mencapai minus sebanyak 206\%, tahun 2012 ke 2013 labanya makin menurun sebanyak 222\%, hingga 2014 penurunannya makin bertambah sebanyak $119 \%$.

Penelitian yang dilakukan oleh Cahyono (2016) menunjukkan bahwa model Z-Score Altman dapat diimplementasikan dalam mendeteksi 
kemungkinan terjadinya kebangkrutan pada perusahaan yang terdaftar di Bursa Efek Indonesia. Berdasarkan latar belakang di atas, di mana kondisi keuangan perusahaan PT Bentoel International Investama Tbk. menggambarkan ketidakstabilan, maka penting sekali untuk menganalisis kondisi perusahaan ke depannya, serta perkembangan dan peningkatan kinerja keuangan pada perusahaan tersebut. Penelitian sejenis juga dilakukan oleh Safitri, dkk (2012) di mana hasil penelitian yang dilakukan terhadap 3 (tiga) perusahaan rokok menunjukkan bahwa terdapat dua perusahaan yang menghasilkan nilai $\mathrm{z}$-score diatas 2,99 yang dikategorikan sehat, sedangkan satu perusahaan menghasilkan nilai $\mathrm{z}$-score di antara 1,81-2,9 yang dikategorikan rawan kebangkrutan.

Adapun tujuan dari penelitian ini adalah untuk menganalisis prediksi kebangkrutan PT. Bentoel International Investama Tbk.

\section{METODE}

Penelitian ini merupakan penelitian kuantitatif deskriptif. Sumber data yang digunakan berupa data sekunder, yaitu data yang diperoleh dari Pusat Informasi Pasar Modal (PIPM) Makassar dan website Bursa Efek Indonesia (www.idx.co.id) berupa laporan keuangan. Teknik pengumpulan data yang dilakukan dalam penelitian ini adalah dokumentasi.

\section{Analisis Data}

Metode analisis data yang digunakan dalam penelitian ini adalah metode Altman Z-Score (1968) yaitu metode untuk memprediksi keberlangsungan hidup suatu perusahaan dengan mengkombinasikan beberapa rasio keuangan yang umum dan pemberian bobot yang berada satu dengan lainnya. Metode Altman menggunakan tiga kriteria yaitu zona aman, grey area dan zona berbahaya. Rumus yang digunakan untuk menganalisis Kebangkrutan dengan menggunakan
Altman Z-score (Wetson \& Copeland, 2010:288) yaitu:

$$
\begin{aligned}
& \text { Z-score }=\mathbf{6 , 5 6} \mathbf{X}_{\mathbf{1}}+\mathbf{3 , 2 6} \mathbf{X}_{\mathbf{2}}+ \\
& \mathbf{6 , 7 2} \mathbf{X}_{\mathbf{3}}+\mathbf{1 , 0 5} \mathbf{X}_{\mathbf{4}} \\
& \text { Dimana : } \\
& \mathrm{X}_{1} \quad=\text { Working Capital To Total Aset } \\
& \mathrm{X}_{2}=\text { Retained Earning To Total Asset } \\
& \mathrm{X}_{3} \quad=\text { Earning Before Interest And Tax } \\
& \text { To Total Asset } \\
& \mathrm{X}_{4} \quad=\text { Market Value Of Equity To Total }
\end{aligned}
$$

\section{Liabilities}

Adapun ketentuan atau Interpretasi Nilai Z-Score, yaitu:

Jika $Z<1,1$ merupakan zona berbahaya, di mana perusahaan dalam kondisi bangkrut.

Jika $1,1<\mathrm{Z}<2,60$ merupakan zona gray area, pada kondisi ini perusahaan mengalami masalah keuangan yang harus ditangani dengan cara yang tepat.

Jika $Z>$ 2,60 merupakan zona aman, di mana perusahaan dalam kondisi sehat sehingga kemungkinan kebangkrutan sangat kecil terjadi.

\section{HASIL DAN PEMBAHASAN}

Hasil penelitian dari prediksi kebangkrutan dengan Metode Altman Z-score menggunakan empat macam rasio. Adapun rasio-rasio tersebut antara lain Net Working Capital To Total Asset, Retained Earning To Total Asset, Earning Before Interest And Tax To Total Asset, Market Value Of Equity To Total Liabilities. Berikut ini adalah perhitungan dari rasiorasio tersebut.

\section{Net Working Capital To Total Asset $\left(\mathbf{X}_{1}\right)$}

Net Working Capital To Total Asset $\left(\mathrm{X}_{1}\right)$ merupakan salah satu rasio untuk mengukur likuiditas perusahaan, dimana jika rasio ini tinggi maka akan menurunkan probabilitas terjadinya kebangkrutan. Rasio likuiditas atau sering juga disebut dengan nama rasio modal kerja bersih yang digunakan untuk mengukur seberapa likuidnya suatu perusahaan. Modal kerja bersih adalah selisih antara aktiva lancar dikurangi hutang lancar pada umumnya, bila 
perusahaan mengalami kesulitan keuangan, modal kerja akan turun lebih cepat. Adapun cara memperoleh Net Working Capital To Total Asset (Kasmir, 2011) adalah:

Net Working Capital To Total Asset

$$
=\frac{\text { Net } \text { Working Capital }}{\text { Total Asset }}
$$

Berikut ini adalah hasil pehitungan dari Net Working Capital To Total Asset PT. Bentoel International Investama Tbk. Untuk tahun 2011-2014.

Tahun 2011, $X_{1=0,07}$. Tahun 2012, $X_{1=}$ 0,25. Tahun 2013, $X_{1}=0,09$. Tahun 2014,

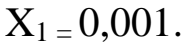

\section{Retained Earning To Total Asset}

Retained Earning To Total Assetmerupakan salah satu rasio untuk mengukur profitabilitas perusahaan, dimana jika rasio ini tinggi maka akan menurunkan potensi terjadinya kebangkrutan. Retained Earning To Total Asset di peroleh dari laporan laba rugi perusahaan tahun 2011 - 2014 sedangkan total aset di peroleh dari neraca perusahaan tahun 2011 - 2014. Adapun rumus dari rasio ini adalah:

Retained Earning To Total Asset

$$
=\frac{\text { Retained Earning }}{\text { Total Asset }}
$$

Berikut ini adalah hasil perhitungan dari rasio Retained Earning To Total Asset $\left(\mathrm{X}_{2}\right)$ untuk tahun $2011-2014$.

Tahun 2011, $\mathrm{X}_{2=}$ 0,26. Tahun 2012, $\mathrm{X}_{2}=$ 0,19 . Tahun 2013, $X_{2}=0,03$. Tahun 2014, $\mathrm{X}_{2}=-0,20$.

\section{Earning Before Intererst and Tax To Total Asset}

Earning Before Intererst and Tax To Total Asset (EBIT) merupakan rasio yang menunjukkan kemampuan perusahaan untuk menghasilkan laba dari aktiva perusahaan, sebelum pembayaran bunga dan pajak. Nilai EBIT $\left(\mathrm{X}_{3}\right)$ diperoleh dari laporan laba rugi perusahaan tahun 20112014 sedangkan total asset di peroleh dari neraca perusahaan tahun 2011 - 2014. Jika rasio ini tinggi maka akan menurunkan potensi terjadinya kebangkrutan. Adapun rumus dari rasio ini adalah:

$$
E B I T=\frac{\text { Net } \text { Working Capital }}{\text { Total Asset }}
$$

Berikut ini adalah hasil perhitungan dari rasio Earnig Before Interest and Tax To Total Asset untuk tahun 2011 - 2014:

Tahun 2011, $X_{3}=0,10$. Tahun 2012, $X_{3=-}$ 0,03 . Tahun 2013, $X_{3}=-0,11$. Tahun 2014, $\mathrm{X}_{3=-}-0,10$.

\section{Market Value Of Equity To Total Liabilities $\left(\mathrm{X}_{\mathbf{4}}\right)$ \\ Market Value Of Equity To Total Liabilities merupakan rasio yang} menunjukkan kemampuan perusahaan dalam memberikan jaminan kepada setiap utangnya melalui modal sendiri (ekuitas). Dimana ekuitas diperoleh dengan mengalikan jumlah lembar saham biasa yang beredar dengan harga per lembar saham biasa. Market Value Of Equity To Total Lialibilities diperoleh dari laporan laba rugi perusahaan 2011 - 2014 sedangkan total Lialibilities di peroleh dari neraca perusahaan tahun 2011 - 2014. Jika rasio ini tinggi maka akan menurunkan potensi terjadinya kebangkrutan. Adapun rumus dari rasio ini adalah:

Market Valueof Equity to Total Liabilities $=\frac{\text { Market Value of Equity }}{\text { Total Liabilities }}$

Berikut ini hasil perhitungan dari Market Value Of Equity To Total Lialibilities untuk tahun 2011-2014:

Tahun 2011, $X_{4}=1,40$. Tahun 2012, $X_{4}=$ 0,84. Tahun 2013, $X_{4}=0,49$. Tahun 2014, $\mathrm{X}_{4}=0,32$.

Setelah seluruh perhitungan rasio telah diketahui, maka keseluruhan hasil perhitungan rasio tersebut akan di kalikan dengan standarnya masing-masing sesuai 
dengan ketentuan model Z-score Altman, kemudian keseluruhan hasil perkalian rasio dengan standarnya masing-masing akan ditambahkan seluruhnya sehingga akan di peroleh suatu nilai atau skor yang memperlihatkan seberapa besar tingkat kebangkrutan usaha PT Bentoel International Investama Tbk. Berikut ini adalah cara perhitungannya:

\section{$Z=6,56 X_{1}+3,26 X_{2}+6,72 X_{3}+1,05 X_{4}$}

Untuk tahun 2011, diperoleh $\mathrm{Z}=3,45$. PT Bentoel International Investama Tbk. untuk periode 2011 , mempunyai nilai $\mathrm{Z}$ sebesar 3,45 yang nilainya lebih besar dari 2,60 sehingga berdasarkan analisis kebangkrutan model Altman Z-score diklasifikasikan sebagai perusahaan yang berada dalam kondisi zona aman, dimana perusahaan dalam kondisi sehat sehingga kemungkinan kebangkrutan sangat kecil terjadi pada tahun 2011.

Untuk tahun 2012, diperoleh $\mathrm{Z}=2$,94. PT Bentoel International Investama Tbk. untuk periode 2012, mempunyai nilai $\mathrm{Z}$ sebesar 2,94 yang nilainya lebih besar dari 2,60 sehingga berdasarkan analisis kebangkrutan model Altman Z-score diklasifikasikan sebagai perusahaan yang berada dalam kondisi zona aman, dimana perusahaan dalam kondisi sehat sehingga kemungkinan kebangkrutan sa ngat kecil terjadi pada tahun 2012.

Untuk tahun 2013, diperoleh $Z=0,46$. PT Bentoel International Investama Tbk. untuk periode 2013, mempunyai nilai $\mathrm{Z}$ sebesar 0,46 yang nilainya lebih kecil dari 1,1 sehingga berdasarkan analisis kebangkrutan model Altman Z-score diklasifikasikan sebagai perusahaan yang berada dalam kondisi zona berbahaya, dimana perusahaan dalam kondisi

bangkrut pada tahun 2013.

Untuk tahun 2014, diperoleh $\mathrm{Z}=-0,98$. PT Bentoel International Investama Tbk. untuk periode 2014 , mempunyai nilai $\mathrm{Z}$ sebesar $(0,98)$ yang nilainya lebih kecil dari 1,1 sehingga berdasarkan analisis kebangkrutan model Altman Z-score diklasifikasikan sebagai perusahaan yang berada dalam kondisi zona berbahaya, di mana perusahaan dalam kondisi bangkrut pada tahun 2014.

Table 1. Rekapitulasi Hasil Perhitungan dengan menggunakan Model Altman Z-score PT Bentoel International Investama Tbk

\begin{tabular}{ccccc}
\hline KET & $\mathbf{2 0 1 1}$ & $\mathbf{2 0 1 2}$ & $\mathbf{2 0 1 3}$ & $\mathbf{2 0 1 4}$ \\
\hline $\mathrm{X}_{1}$ & 0,07 & 0,25 & 0,09 & 0,001 \\
$\mathrm{X}_{2}$ & 0,26 & 0,19 & 0,03 & $-0,20$ \\
$\mathrm{X}_{3}$ & 0,10 & $-0,03$ & $-0,11$ & $-0,10$ \\
$\mathrm{X}_{4}$ & 1,40 & 0,84 & 0,49 & 0,32 \\
\hline Altman Z-score & 3,45 & 2,94 & 0,46 & $-0,98$ \\
\hline Prediksi & Zona Aman & Zona Aman & Zona Berbahaya & Zona Berbahaya \\
\hline
\end{tabular}

Tahun 2011

Pada tabel 1 menunjukkan bahwa untuk tahun 2011 diperoleh Z-score sebesar 3,45 yang berarti perusahaan dalam zona aman di mana pada interpretasi Altman Z-score diatas 2,60 berarti dalam zona aman yang artinya perusahaan dalam kondisi sehat sehingga kebangkrutan sangat kecil terjadi pada PT. Bentoel International Investama. Tbk,
Dilihat dari :

a. Net Working Capital To Total Asset $\left(\mathrm{X}_{1}\right)$

Rasio net working to total asset bernilai positif sebesar 0,07 atau $7 \%$ total asset yang dibiayai dari utang jangka panjang perusahaan. Di mana aktiva lancar perusahaan lebih tinggi dibandingkan dengan hutang lancar perusahaan yang mampu membayar 
utang jangka pendeknya artinya perusahaan dalam keadaan liquid.

b. Retained Earning To Total Asset $\left(\mathrm{X}_{2}\right)$

Rasio Retained Earning To Total Asset (profitabilitas) mendapatkan hasil yang positif sebesar 0,26 atau $26 \%$. Yang berarti perusahaan menghasilkan saldo laba ditahan dari setiap Total Asset yang digunakan sehingga perusahaan menghasilkan laba bersih yang dapat dimasukkan pada modal laba ditahan perusahaan.

c. Earning Before Interest and Tax To Total Asset $\left(\mathrm{X}_{3}\right)$

Rasio Earning Before Interest and Tax To Total Asset (profitabilitas) mendapatkan hasil yang positif sebesar 0,10 atau $10 \%$ yang berarti perusahaan mampu menghasilkan laba operasi dari total aktiva perusahaan yang digunakan. Sebelum pembayaran bunga dan pajak sehingga perusahaan tetap menghasilkan laba.

d. Market Value of equity To Total Liabilities $\left(\mathrm{X}_{4}\right)$

Rasio Market Value of equity To Total Liabilities (solvabilitas) mendapatkan hasil yang positif sebesar 1,40 atau $140 \%$ yang berarti perusahaan dapat menjamin setiap total hutang dari ekuitas yang dimilikinya.

\section{Tahun 2012}

Pada tabel 1 menunjukkan bahwa untuk tahun 2012 diperoleh Z-score sebesar 2,94 yang berarti perusahaan dalam zona aman di mana pada interpretasi Altman Z-score di atas 2,60 berarti dalam zona aman yang artinya perusahaan dalam kondisi sehat sehingga kebangkrutan sangat kecil terjadi pada PT. Bentoel International Investama. Tbk, Dilihat dari :

a. Net Working Capital To Total Asset $\left(\mathrm{X}_{1}\right)$

Rasio net working to total asset bernilai positif sebesar 0,25 atau $25 \%$ total asset yang dibiayai dari utang jangka panjang perusahaan. Dimana aktiva lancar perusahaan lebih tinggi dibandingkan dengan hutang lancar perusahaan yang mampu membayar utang jangka pendeknya artinya perusahaan dalam keadaan liquid.

\section{b. Retained Earning To Total Asset $\left(\mathrm{X}_{2}\right)$}

Rasio Retained Earning To Total Asset (profitabilitas) mendapatkan hasil yang positif sebesar 0,19 atau 19\%. Yang berarti perusahaan menghasilkan saldo laba ditahan dari setiap Total Asset yang digunakan sehingga perusahaan menghasilkan laba bersih yang dapat dimasukkan pada modal laba ditahan perusahaan. Namun pada tahun 2012 mengalami penurunan laba ditahan dari tahun sebelumnya sebesar $7 \%$ yang di akibatkan oleh pendapatan bersih menurun sebesar 2,19\% sedangkan beban pokok penjualan meningkat sebesar $5 \%$ dan beban operasional juga mengalami peingkatan sebesar $11 \%$.

c. Earning Before Interest and Tax To

Total Asset $\left(\mathrm{X}_{3}\right)$

Rasio Earning Before Interest and Tax To Total Asset (profitabilitas) mendapatkan hasil yang negatifsebesar $-0,03$ atau $3 \%$ yang berarti perusahaan tidak mampu menghasilkan laba operasi dari total aktiva perusahaan yang digunakan, sebelum pembayaran bunga dan pajak, sehingga perusahaan tidak mampu menghasilkan laba dari hasil operasi atas aktiva yang telah digunakannya, akan berdampak pada kerugian. Penyebab kerugian ini pada tahun 2012 mengalami penurunan Earning Before Interest and Tax dari tahun sebelumnya sebesar $7 \%$ yang di akibatkan oleh pendapatan bersih menurun sebesar $2,19 \%$ sedangkan beban pokok penjualan meningkat sebesar 5\% dan beban operasional juga mengalami peningkatan sebesar $11 \%$.

d. Market Value of equity To Total Liabilities $\left(\mathrm{X}_{4}\right)$

Rasio Market Value of equity To Total Liabilities (solvabilitas) mendapatkan 
hasil yang positif sebesar 0,84 atau 84 $\%$ yang berarti nilai perusahaan dapat menjamin setiap total hutang dari ekuitas yang dimilikinya. Namun pada tahun 2012 Market value of equity mengalami penurunan dari tahun sebelumnya sebesar 56\% yang diakibatkan oleh harga saham perusahaan yang menurun sebesar $26 \%$ sedagkan total utang mengalami peningkatan sebesar $22 \%$.

\section{Tahun 2013}

Pada tabel 1 menunjukkan bahwa untuk tahun 2013 diperoleh $Z$ score sebesar 0,46 yang berarti perusahaan dalam zona berbahaya di mana pada interpretasi Altman Z-score dibawah 1,1 berarti dalam zona berbahaya yang artinya perusahaan dalam kondisi bangkrut sehingga di prediksi mengalami kemungkinan kebangkrutan pada PT. Bentoel International Investama Tbk. dilihat dari :

\section{a. Net Working Capital to Total Asset} $\left(\mathrm{X}_{1}\right)$

Rasio net working to total asset bernilai positif sebesar 0,09 atau $9 \%$ total asset yang dibiayai dari utang jangka panjang perusahaan. Dimana aktiva lancar perusahaan lebih tinggi dibandingkan dengan hutang lancar perusahaan yang mampu membayar utang jangka pendeknya artinya perusahaan dalam keadaan liquid.

b. Retained Earning to Total Asset $\left(\mathrm{X}_{2}\right)$

Rasio Retained Earning to Total Asset (profitabilitas) mendapatkan hasil yang positif sebesar 0,03 atau $3 \%$. Yang berarti perusahaan menghasilkan saldo laba ditahan dari setiap Total Asset yang digunakan sehingga perusahaan menghasilkan laba bersih yang dapat dimasukkan pada modal laba ditahan perusahaan. Namun pada tahun 2012 mengalami penurunan laba ditahan dari tahun sebelumnya sebesar $16 \%$ yang di akibatkan oleh pendapatan bersih meningkat sebesar $24 \%$ sedangkan beban pokok penjualan lebih mengalami peningkatan sebesar $28 \%$ dan beban operasional juga mengalami peingkatan sebesar $47 \%$.

c. Earning Before Interest and Tax To Total Asset $\left(\mathrm{X}_{3}\right)$

Rasio Earning Before Interest and Tax to Total Asset (profitabilitas) mendapatkan hasil yang negatifsebesar $-0,11$ atau $11 \%$ yang berarti perusahaan tidak mampu menghasilkan laba operasi dari total aktiva perusahaan yang digunakan, sebelum pembayaran bunga dan pajak, sehingga perusahaan tidak mampu menghasilkan laba dari hasil operasi atas aktiva yang telah digunakannya, akan berdampak pada kerugian. Penyebab kerugian ini pada tahun 2013 mengalami penurunan Earning Before Interest and Tax dari tahun sebelumnya sebesar $8 \%$ yang diakibatkan oleh pendapatan bersih meningkat sebesar $24 \%$ sedangkan beban pokok penjualan lebih mengalami peningkatan sebesar $28 \%$ dan beban operasional juga mengalami peningkatan yang sangat tinggi sebesar $47 \%$.

d. Market Value of Equity To Total Liabilities $\left(\mathrm{X}_{4}\right)$

Rasio Market Value of equity to Total Liabilities (solvabilitas) mendapatkan hasil yang positif sebesar 0,49 atau $49 \%$ yang berarti nilai perusahaan dapat menjamin setiap total hutang dari ekuitas yang dimilikinya. Namun pada tahun 2013 Market value of equity mengalami penurunan dari tahun sebelumnya sebesar $35 \%$ yang diakibatkan oleh harga saham perusahaan yang menurun sebesar $10 \%$ sedagkan total utang mengalami peningkatan sebesar $66 \%$.

\section{Tahun 2014}

Pada tabel 1 menunjukkan bahwa untuk tahun 2014 diperoleh Z-score sebesar $-0,98$ yang berarti perusahaan dalam zona berbahaya di mana pada interpretasi Altman Z-score di bawah 
1,1 berarti dalam zona berbahaya yang artinya perusahaan dalam kondisi bangkrut sehingga di prediksi mengalami kemungkinan kebangkrutan pada PT. Bentoel International Investama. Tbk, Dilihat dari :

a. Net Working Capital to Total Asset $\left(\mathrm{X}_{1}\right)$

Rasio net working to total asset bernilai positif sebesar 0,001 atau $1 \%$ total asset yang dibiayai dari utang jangka panjang perusahaan. Dimana aktiva lancar perusahaan lebih tinggi dibandingkan dengan hutang lancar perusahaan yang mampu membayar utang jangka pendeknya artinya perusahaan dalam keadaan liquid.

b. Retained Earning to Total Asset $\left(\mathrm{X}_{2}\right)$ Rasio Retained Earning to Total Asset (profitabilitas) mendapatkan hasil yang negative sebesar -20 atau $20 \%$. Yang berarti perusahaan tidak mampu menghasilkan devisit saldo laba di tahan dari setiap total asset yang digunakannya.sedangkan pada tahun 2014 perusahaan mengalami devisit saldo laba ditahan dari tahun sebelumnya sebesar $17 \%$ yang di akibatkan oleh pendapatan bersih meningkat sebesar $14 \%$ diikuti oleh peningkatan beban pokok penjualan sebesar 19\%. Beban pokok penjualan lebih besar peningkatannya dibandingkan dengan peningkatan pendapatan bersih walaupun beban operasional mengalami penurunan sebesar $8 \%$.

c. Earning Before Interest and Tax to Total Asset $\left(\mathrm{X}_{3}\right)$

Rasio Earning Before Interest
and Tax to Total Asset
(profitabilitas) mendapatkan hasil yang negatifsebesar -0,10atau 10\% yang berarti perusahaan tidak mampu menghasilkan laba operasi dari total aktiva perusahaan yang digunakan, sebelum pembayaran bunga dan pajak, sehingga perusahaan tidak mampu menghasilkan laba dari hasil operasi atas aktiva yang telah digunakannya, akan berdampak pada kerugian. Penyebab kerugian ini pada tahun 2014 mengalami penurunan pada Earning Before Interest and Tax dari tahun sebelumnya sebesar $1 \%$ yang di akibatkan oleh pendapatan bersih meningkat sebesar $14 \%$ diikuti oleh peningkatan beban pokok penjualan sebesar 19\%. Beban pokok penjualan lebih besar peningkatannya dibandingkan dengan peningkatan pendapatan bersih walaupun beban operasional mengalami penurunan sebesar $8 \%$.

d. Market Value of Equity to Total Liabilities $\left(\mathrm{X}_{4}\right)$

Rasio Market Value of Equity to Total Liabilities (solvabilitas) mendapatkan hasil yang positif sebesar 0,32 atau $32 \%$ yang berarti nilai perusahaan dapat menjamin setiap total hutang dari ekuitas yang dimilikinya. Namun pada tahun 2012 Market value of equity mengalami penurunan dari tahun sebelumnya sebesar $17 \%$ yang diakibatkan oleh harga saham perusahaan yang meningkat sebesar 9\% sedangkan total utang mengalami peningkatan sebesar $34 \%$.

Berdasarkan uraian di atas, PT Bentoel International Investama Tbk. mengalami penurunan laba selama beberapa tahun terakhir, di mana diprediksi bangkrut pada tahun 2014 disebabkan karena pendapatan bersih di tahun 2013 meningkat sebesar $24 \%$ tetapi peningkatan beban penjualan lebih tinggi yaitu sebesar $28 \%$ dan diikuti beban operasional sebesar $\quad 47 \%$ dibandingkan pendapatan bersih perusahaan sehingga perusahaan mengalami kerugian. Pada tahun 2014 pendapatan bersih meningkat sebesar $14 \%$ diikuti oleh peningkatan beban penjualan lebih besar yaitu sebesar 
19\% walaupun beban operasional menurun sebesar $8 \%$ namun belum mampu menutupi kerugian perusahaan. Sehingga perusahaan mengalami kerugian di tahun 2013 dan 2014. Di mana laba ditahan digunakan untuk menutupi kerugian sehingga laba ditahan dari tahun ketahun mengalami penurunan, harga saham perusahaan di pasar modal terjadi penurunan harga setiap tahunnya.

\section{KESIMPULAN DAN SARAN}

Berdasarkan hasil penelitian yang dilakukan pada PT Bentoel International Investama Tbk. di Bursa Efek Indonesia (BEI), dilihat dari $\mathrm{X}_{1}$ (Net Working Capital to Total Asset) daritahun 2011 2014 perusahaan dalam keadaan liquid, $\mathrm{X}_{2}$ (Retained Earning to Total Asset) dari tahun 2011 - 2014 perusahaan mengalami penurunan laba ditahan sampai dalam keadaan defisit, $\mathrm{X}_{3}$ (Earning Before Interest and Tax to Total Asset) dari tahun 2011 - 2014 perusahaan mengalami penurunan hasil laba sebelum bunga dan pajak sampai perusahaan mengalami rugi sebelum bunga dan pajak, dan $\mathrm{X}_{3}$ (Market Value Of Equity To Total Asset) dari tahun 2011 - 2012 perusahaan mengalami penurunan nilai perusahaan dari tahun ketahun hingga tidak mampu menutupi total hutangnya. Sehingga dapat ditarik kesimpulan bahwa PT. Bentoel International Investama Tbk. pada tahun 2015 berpotensi mengalami kebangkrutan.

Saran yang dikemukakan dalam penelitian ini untuk pihak-pihak yang berkepentingan di masa mendatang demi pencapaian manfaat yang optimal, dan pengembangan dari hasil penelitian adalah: Bagi PT Bentoel International Investama Tbk. harus lebih menekan beban penjualan dan beban operasional agar lebih efisien, dan untuk peneliti selanjutnya, disarankan untuk mencoba model lain selain model Z-Score Altman sehingga hasil yang diperoleh bisa diperbandingkan.

\section{UCAPAN TERIMA KASIH}

Ucapan terima kasih kami sampaikan kepada semua pihak dalam lingkup Universitas Indonesia Timur yang telah ikut membantu dalam penyelesaian penelitian ini serta para pegawai yang ada di perpustakan PIPM (IDX) yang berada di kantor cabang Makassar.

\section{DAFTAR PUSTAKA}

Altman, E. (1968). Financial Ratios, Discriminant and the Prediction of Corporate Bankruptcy. Journal of Finance 23, September 1968.

Ambarwati, Dwi, Ari, 2010. Manajemen Keuangan Lanjut, Cetakan Pertama, Yogyakarta, Graha Ilmu.

Cahyono, Wijaya dan Moel Jadi. 2016. Prediksi Kebangkrutan Perusahaan Pertambangan Batubara yang Listing di Bursa Efek Indonesia periode 2011-2012 Dengan Menggunakan Analisis Model ZScore Altman. Jurnal Ilmiah Mahasiswa FEB, Volume 1 Nomor 2.

Fahmi, Irham, 2011. Analisis Laporan Keuangan. Bandung : Penerbit Alfabeta.

Frank H. Dixon. 1994. Understanding Bankruptcy. Publiched :Osxford and Cambridge Business Press Ltd

Kasmir. 2011. Analisis Laporan Keuangan, Jakarta: PT. Raja Grafindo Persada.

May, Ellen. Diakses tanggal 3 Februari 2018. Prospek Perusahaan

Tembakau di 2017. https://finance.detik.com/market -research/d-3412744/prospekperusahaan-tembakau-di-2017saham-apa-yang-terimbas

Rahayu, Ayu. 2011. Analisis Prediksi Kebangkrutan Usaha pada 
Industri Tekstil yang Terdaftar

di Bursa Efek Indonesia.

Makassar : STIM Nitro

Rodoni, Ahmad dan Ali Herni. 2014.

Manajemen Keuangan Modern.

Jakarta: Penerbit Mitra Wacana

Media

Rudianto. 2013. Akuntansi Manajemen.

Jakarta: Penerbit Erlangga.

Safitra, Kertahadi. Dkk. 2012. "Analisis

Metode Altman (Z-Score)

Sebagai Alat Evaluasi Guna

Memprediksi Kebangkrutan

Perusahaan (Studi pada Industri

Rokok yang Terdaftar Di BEI

Periode 2007-2011)", Skripsi,

Fakultas Ilmu Administrasi

Universitas Brawijaya.

UUD Republik Indonesia Nomor 36

Tahun 2009 Tentang Kesehatan

Wetson, J. Fred dan Thomas E. Copeland. 2010. Manajemen Keuangan, Alih Bahasa oleh A. Jaka Wasana dan Kibrandoko, Edisi Revisi, Jilid Idan 2. Jakarta: Binarupa Aksara.

www.idx.co.id (Diakses tanggal 29 Januari 2016). 